\title{
Operating Strategies to Minimize Degradation in Fuel Cell Gas Turbine Hybrids
}

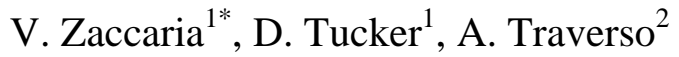 \\ ${ }^{1}$ U.S. Department of Energy, NETL, Morgantown, WV, USA \\ 2 Thermochemical Power Group, Università di Genova, Genova, Italy \\ * Corresponding author: 3610 Collins Ferry Rd, Morgantown, WV 26507 \\ valentina.zaccaria@netl.doe.gov
}

Abstract - The hybridization of solid oxide fuel cell (SOFC) and gas turbine technologies provides an increase in system efficiency and economic performance. The latter aspect is significantly affected by fuel cell degradation, due to several mechanisms. However, hybrid systems allow different control strategies to minimize degradation effects on system performance and their impact on economic feasibility.

A real-time distributed model of a SOFC was used to simulate fuel cell degradation in the cases of a standalone stack and a hybrid configuration, in the latter of which the numerical model is normally coupled with the hybrid system hardware components of the National Energy Technology Laboratory (NETL) Hyper facility. The results showed how in a hybrid system it is possible, with an appropriate strategy, to maintain constant voltage even if the cell is degrading, reducing degradation rate during time. At constant power demand, fuel cell life could be significantly extended using the operating strategies allowed by coupling with a turbine (an order of magnitude longer than a standalone fuel cell), maintaining high system efficiency despite fuel cell degradation.

Keywords - Control strategies, degradation, hybrid systems, SOFC

\section{Nomenclature}

\begin{tabular}{|c|c|c|c|}
\hline ASR & area specific resistance $\left[\Omega \cdot \mathrm{m}^{2}\right]$ & $F$ & Faraday's constant $[\mathrm{C} / \mathrm{mol}]$ \\
\hline $\mathrm{CF}$ & cash flow $[\$]$ & $G$ & Gibbs free energy $[\mathrm{kJ}]$ \\
\hline FU & fuel utilization & $h$ & specific enthalpy variation \\
\hline LHV & low heating value $[\mathrm{kJ} / \mathrm{kg}]$ & & reference condition $(298 \mathrm{~K})[\mathrm{kJ} / \mathrm{kg}]$ \\
\hline LSM & lanthanum strontium manganite & $i$ & current density $\left[\mathrm{A} / \mathrm{cm}^{2}\right]$ \\
\hline NPV & net present value $[\$]$ & $i_{0}$ & exchange current density $\left[\mathrm{A} / \mathrm{cm}^{2}\right]$ \\
\hline PBP & payback period [yr] & $k$ & thermal conductivity $[\mathrm{W} / \mathrm{m} \cdot \mathrm{K}]$ \\
\hline PID & proportional integrative derivative & $\mathrm{L}$ & fuel cell length $[\mathrm{m}]$ \\
\hline SOFC & solid oxide fuel cell & $\dot{m}$ & mass flow rate $[\mathrm{kg} / \mathrm{s}]$ \\
\hline TCI & total capital investment [\$] & $n$ & number of electrons transfer per \\
\hline TPB & triple phase boundary & & reaction \\
\hline \multirow[t]{2}{*}{ YSZ } & yttria-stabilized zirconia & $\dot{n}$ & molar flow rate $[\mathrm{mol} / \mathrm{s}]$ \\
\hline & & $P$ & turbine power $[\mathrm{kW}]$ \\
\hline$A$ & area $\left[\mathrm{m}^{2}\right]$ & $p$ & partial pressure [atm] \\
\hline$C_{f}$ & fuel consumption [kg] & $\dot{Q}$ & transferred heat $[\mathrm{kW}]$ \\
\hline$c_{p}$ & specific heat $[\mathrm{J} / \mathrm{kg} \cdot \mathrm{K}]$ & $q_{g e n}$ & specific generated heat $[\mathrm{W} / \mathrm{m}]$ \\
\hline$E_{e l}$ & electricity production $[\mathrm{kWh}]$ & $R_{g}$ & ideal gas constant $[\mathrm{J} / \mathrm{mol} \cdot \mathrm{K}]$ \\
\hline
\end{tabular}




$\begin{array}{llll}r & \text { internal rate } & \eta_{G T} & \text { gas turbine efficiency } \\ r_{d} & \text { degradation rate }[\% / \mathrm{kh}] & v & \text { stoichiometric coefficient } \\ T & \text { temperature }[\mathrm{K}] \text { or }\left[{ }^{\circ} \mathrm{C}\right] & \rho & \text { density }\left[\mathrm{kg} / \mathrm{m}^{3}\right] \\ V & \text { voltage, overpotential }[\mathrm{V}] & & \\ x & \text { molar fraction } & \text { act } & \text { activation } \\ & & \text { dif } & \text { diffusion } \\ \alpha & \text { charge transfer coefficient } & \text { ohm } & \text { ohmic }\end{array}$

\section{Introduction}

Extensive on-going research on high temperature fuel cells such as Solid Oxide Fuel Cells (SOFCs) have proven these devices to be a promising technology for energy conversion. Their high fuel-to-electricity efficiency, up to $50 \%$, the reduced $\mathrm{CO}_{2}$ emissions and negligible $\mathrm{NO}_{\mathrm{x}}$ and $\mathrm{SO}_{\mathrm{x}}$ emissions, together with a very low noise level, make SOFCs attractive for stationary power production. Due to the significant amount of high quality generated heat, in co-generation systems the total efficiency could reach $85 \%$ [1].

Coupling the SOFC with a bottoming gas turbine cycle to recover the available heat can lead to significantly higher electrical efficiency and increase the system flexibility [2-5]. The turbine recovers the waste heat from the fuel cell and the unutilized fuel enhancing the power production and the global efficiency as high as $60 \%$ on coal (through gasification) and above $70 \%$ on natural gas $[4,5]$. On the other hand, the compressor is used to pressurize the fuel cell and pre-heat the cathode stream at no additional cost, further improving fuel cell performance.

SOFC high operating temperature (between 600 and $900^{\circ} \mathrm{C}$ ) is favorable not only in terms of efficiency, but also in terms of fuel flexibility, since internal methane reforming and water-gas-shift reactions are possible [6]. However, temperature fluctuations, thermal stresses, and presence of impurities in the fuel can induce severe performance degradation over time, limiting the economic feasibility of this technology. Thermal cycles and different thermal properties of the materials that constitute the cell can cause electrolyte cracking and electrodes delamination, segregation, and detachment [7, 8]. Fuel contaminants can block the fuel channels or react with the catalyst, provoking in both cases an increment in polarization and a reduction in power output [9, 10]. Carbon deposition, sulfur and chromium poisoning of the electrodes are also causes of performance degradation and limited fuel cell life [10, 11].

The influence of stack operating conditions on degradation was widely investigated in the open literature [12, 13]. Hagen et al. experimentally observed that high current density and low temperature accelerate cell degradation [12]. Nakajo et al. employed a detailed, semi-empirical model of several degradation mechanisms to evaluate the SOFC lifetime at different operating conditions, and concluded that lower power density and higher temperature promoted lower degradation [13]. Both of these studies suggested that the control of stack current density and temperature could mitigate degradation phenomena. Moreover, fuel utilization control was considered fundamental to avoid anode re-oxidation $[13,14]$.

The effects of cell degradation on the performance of a fuel cell gas turbine hybrid system have not been deeply considered so far. A preliminary lifetime assessment showed the potential of systems hybridization to extend fuel cell life [15]. Those promising results were the motivation for the more extensive study presented in this paper. In this work, five different operating strategies 
were tested on an atmospheric SOFC stack and an SOFC gas turbine hybrid system, with the goal of minimizing degradation effects on system performance. The lifetime comparison could be the starting point for a future economic analysis to determine the benefit of a hybrid system and the optimal operative strategy along plant life. This analysis will be used in the framework of the European project "BioHypp", which aims to build and test a real fuel cell gas turbine hybrid plant.

\section{Background}

Due to the currently very high cost of fuel cell stacks, numerical models play a valuable role for the study of SOFCs and SOFC hybrids in terms of dynamics and control. In particular, numerical studies on hybrid systems demonstrated high performance at both full- and part-load conditions, and improved system flexibility during transients compared to standalone fuel cells [16]. Evaluating optimal control strategies was also the objective of many efforts: components matching [17], temperatures control [18, 19], and load following [20, 21] are some examples. In particular, a distinction can be made between dynamic and supervisory controls, the latter often based on optimization approaches. In the open literature, mainly low-level controls are applied to SOFC systems.

The main goals that a control strategy should accomplish could be considered: good load following, sufficiently high efficiency in off-design conditions, and long components lifetime, i.e. reduced components degradation. To address these requirements, parameters such as fuel cell temperature and fuel flow have been considered in the literature as key control variables [22-26]. Among low-level controls, a combination of PIs and feedforward controllers was proposed by Ferrari in order to limit temperature and fuel utilization oscillations in the system and achieve fast response during load variations [22]. The control strategy included the control of SOFC power, fuel utilization, fuel cell temperature, and gas turbine power. Different control architectures were evaluated to avoid fuel starvation and excessive temperature variations during load following [2325]. Aguiar et al. proposed a two-loop control system where a master (supervisory) controller fixed air and fuel flows according with the power demand and a PID controller adjusted the airflow around the value imposed by the master controller in order to keep constant outlet gas temperature [26].

Multi-variable model predictive control has been used to minimize thermal stresses in a SOFC and improve lifetime [27-29]. Model predictive control was also employed successfully as supervisory control in an SOFC hybrid system, where the MPC manipulated the set-point of lower level PIDs [30]. Huang et al. showed that smooth control and better performance can be obtained by using MPC [31]. Supervisory control systems were often applied to PEM fuel cells to improve performance and durability [32-34].

The regulation of current, temperature, and fuel utilization during the cell operating life is expected to influence cell degradation evolution, hence fuel cell lifetime [12, 13]. An optimization framework have been employed so far to minimize degradation effects in a standalone SOFC, which could give useful indications for the design of a supervisory control system [35]. The novelty of the present work is to compare the possible operating strategies to offset or mitigate cell degradation in a standalone SOFC stack and in a hybrid system, discussing benefits and limitations of such strategies in terms of fuel cell durability. These information can be integrated in the future in a high-level supervisory control system. 
The real-time, dynamic SOFC model employed in this work was developed for hardware-based simulations of a hybrid system [36]. The main difference with most degradation models presented in the literature $[13,37]$ is the real-time capability that allows the coupling with the hardware components and facilitates control research. To maintain short computational times, detailed degradation mechanisms were not considered, and an empirical model was developed. Previous work by the authors focused on empirical model development, lifetime assessment, and detailed model characterization $[15,38,39]$.

Nease and Adams evaluated the potential of integrated gasifier SOFC systems in terms of efficiency, cost, and emissions, compared to other coal-fueled plants [40]. The lifetime of the SOFC was assumed 10 years according to the future target. With the more detailed insight of lifetime characterization presented in this work, a more complete life cycle assessment at the stateof-the-art could be performed for SOFC and SOFC hybrids.

\section{SOFC model description}

In order to study the life of a SOFC fed by syngas, a real-time, 1D model was implemented in MATLAB Simulink ${ }^{\mathrm{TM}}$, in which voltage degradation during time was simulated using an empirical expression for the degradation rate (percentage of voltage drop per 1000 hours of operation) as function of current density $i$, fuel utilization $F U$ and temperature $T$ [38]. More details of the model can be found in previous publications [36, 38].

The simulated fuel cell was a planar, co-flow, anode-supported SOFC. Nickel doped yttriastabilized zirconia (Ni-YSZ), YSZ- lanthanum strontium magnetite (LSM), and YSZ were used as anode, cathode, and electrolyte respectively, with metallic interconnect. In order to meet both the accuracy and real-time performance requirement, the cell model was discretized in 20 volumes and a finite volume approach was employed for the electrochemical equations, while a finite different method was used to solve the thermodynamic problem. Fuel cell output variables are calculated as distributed profiles along the cell. The fundamental equations are reported here: Nernst potential (Eq. 1) is calculated considering only hydrogen oxidation, cell voltage (Eq. 2) is calculated from Nernst potential from which the overpotentials (Eq. 3-5) are subtracted.

$$
\begin{aligned}
& V_{N E R N S T}=-\frac{\Delta G_{\mathrm{H}_{2} \mathrm{O}}^{0}}{n F}+\frac{R_{g} T}{n F} \ln \left(\frac{p_{\mathrm{H}_{2}} \sqrt{p_{\mathrm{O}_{2}}}}{p_{\mathrm{H}_{2} \mathrm{O}}}\right) \\
& V_{\text {cell }}=V_{\text {NERNST }}-V_{\text {dif }}-V_{\text {act }}-V_{\text {ohm }} \\
& V_{\text {dif }}=\frac{R_{g} T}{2 F}\left(\ln \left(\frac{x_{\mathrm{H}_{2}, \text { bulk }} \cdot x_{\mathrm{H}_{2} \mathrm{O}, T P B}}{x_{\mathrm{H}_{2} \mathrm{O}, \text { bulk }} \cdot x_{\mathrm{H}_{2}, T P B}}\right)+\frac{1}{2} \ln \left(\frac{x_{\mathrm{O}_{2}, \text { bulk }}}{x_{O_{2}, T P B}}\right)\right) \\
& V_{\text {act }}=\frac{R_{g} T}{\alpha n F} \sinh ^{-1}\left(\frac{i}{2 i_{0}}\right) \\
& V_{\text {ohm }}=A S R \cdot i
\end{aligned}
$$

The empirical expression for the degradation rate $(\% / \mathrm{kh})$ as function of three key operating parameters is presented in Equation 6. This algebraic function was found with a curve fit method from experimental data, as described in previous work [38]. A localized degradation model, 
although simplified, allowed localized effects of temperature and current density to be taken into account.

$r_{d}=\frac{0.59 F U+0.74}{1+\exp \left(\frac{T-1087}{22.92}\right)}\left(e^{2.64 i}-1\right)$

Degradation rate was assumed to impact only the ohmic area specific resistance (ASR) of the cell, and consequently the ohmic losses as shown in Eq. 5. In particular, at each sample time the ASR was incremented by a factor $r_{d}$. A detailed characterization of the degradation model can be found in previous publications [38]. The material set and fuel composition assumed for this work are the same employed to collect the experimental data on degradation to ensure the consistence of the empirical expression. More details can be found in [38]. The impact of fuel impurities was not taken into account. The same expression was used for both atmospheric and pressurized cell, not considering the effect of pressure on degradation mechanisms.

Temperature distributions along the cell were calculated solving Equation 7, which accounts for the heat generated by the chemical reactions $q_{g e n}$, the conductive heat transfer in the solid material, and the convective transfer between air flow and solid.

$k A_{\text {channel }} \frac{\partial^{2} T}{\partial x^{2}}+\frac{h}{L} A_{\text {gas }}\left(T_{\infty}-T\right)+q_{\text {gen }}=\rho c_{p} A_{\text {channel }} \frac{\partial T}{\partial t}$

The model could simulate a standalone fuel cell or a hybrid configuration where the waste heat from the fuel cell system was converted into electrical power by a gas turbine. The recuperated gas turbine cycle was not modeled in this work, but only the power generated by the turbine was calculated from the fuel cell system available heat, as illustrated in Equations 8 and 9. The available heat was based on the specific enthalpy variations of the inlet and outlet streams (see also Fig. 2b).

$\dot{Q}=\dot{m}_{\text {out }} h_{2}-\dot{m}_{\text {in }} h_{1}$

$P=\eta_{G T} \cdot \dot{Q}$

The recuperated gas turbine cycle efficiency $\eta_{G T}$ as function of power is plotted in Figure 1. 


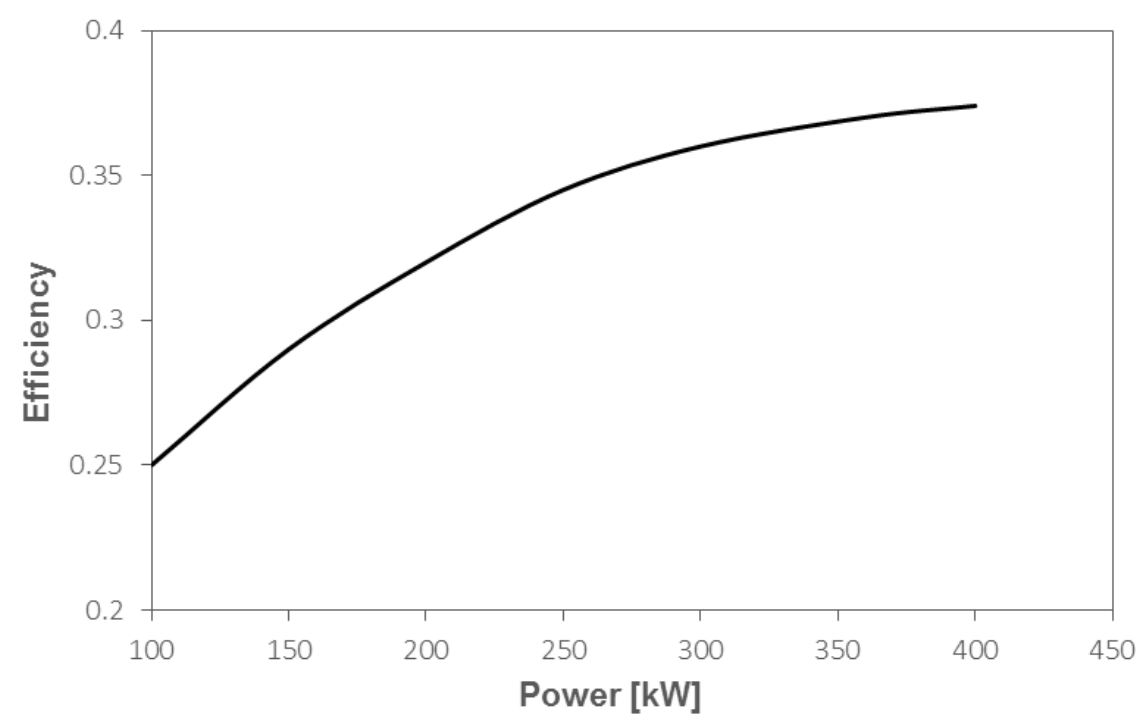

Fig. 1. Gas turbine cycle efficiency map

A schematic representation of the standalone fuel cell system model is illustrated in Figure 2a, where the fuel cell is operated in atmospheric conditions. The fuel cell was a single-pass type without recirculation. The unutilized fuel from the anode side was mixed with the cathode stream in a post-combustor where the fuel was completely oxidized. A heat exchanger was used to preheat the cathode inlet airflow with the post-combustor exhausts. This component was used to represent the heat exchange in the air manifold. In the hybrid system, where the fuel cell operated in pressurized conditions, the hot gas leaving the heat exchanger was sent to the gas turbine (Figure 2b). In addition, a pre-heat combustor was located upstream of the cathode in order to regulate the air temperature [41].

The gas temperature at the exit of pre- and post-combustor was calculated by solving Equation 10, where $i$ represents each chemical species. The combustion was considered adiabatic and complete, and no dissociation phenomena were considered due to the amount of excess air and lower combustion temperatures.

$$
\sum_{i} \dot{n}_{i} v_{i}\left(H_{i}^{0}+\int_{T_{1}}^{T_{2}} c_{p, i} d T\right)=0
$$

a)

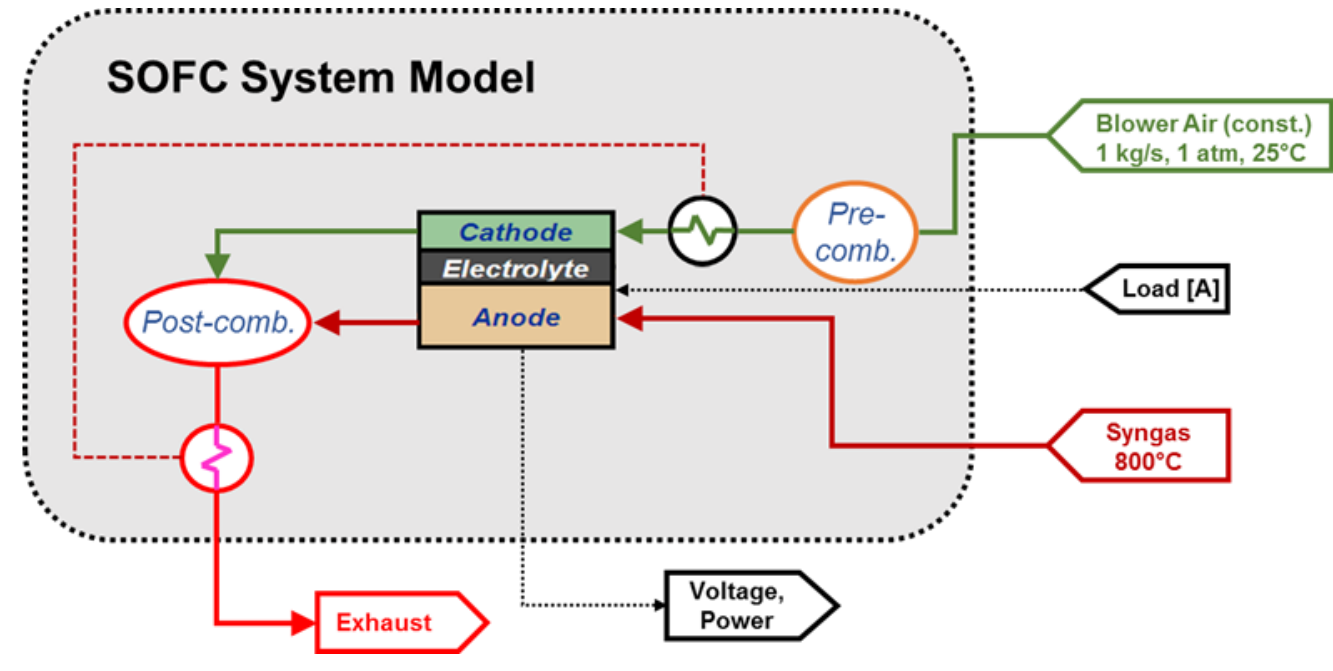


b)

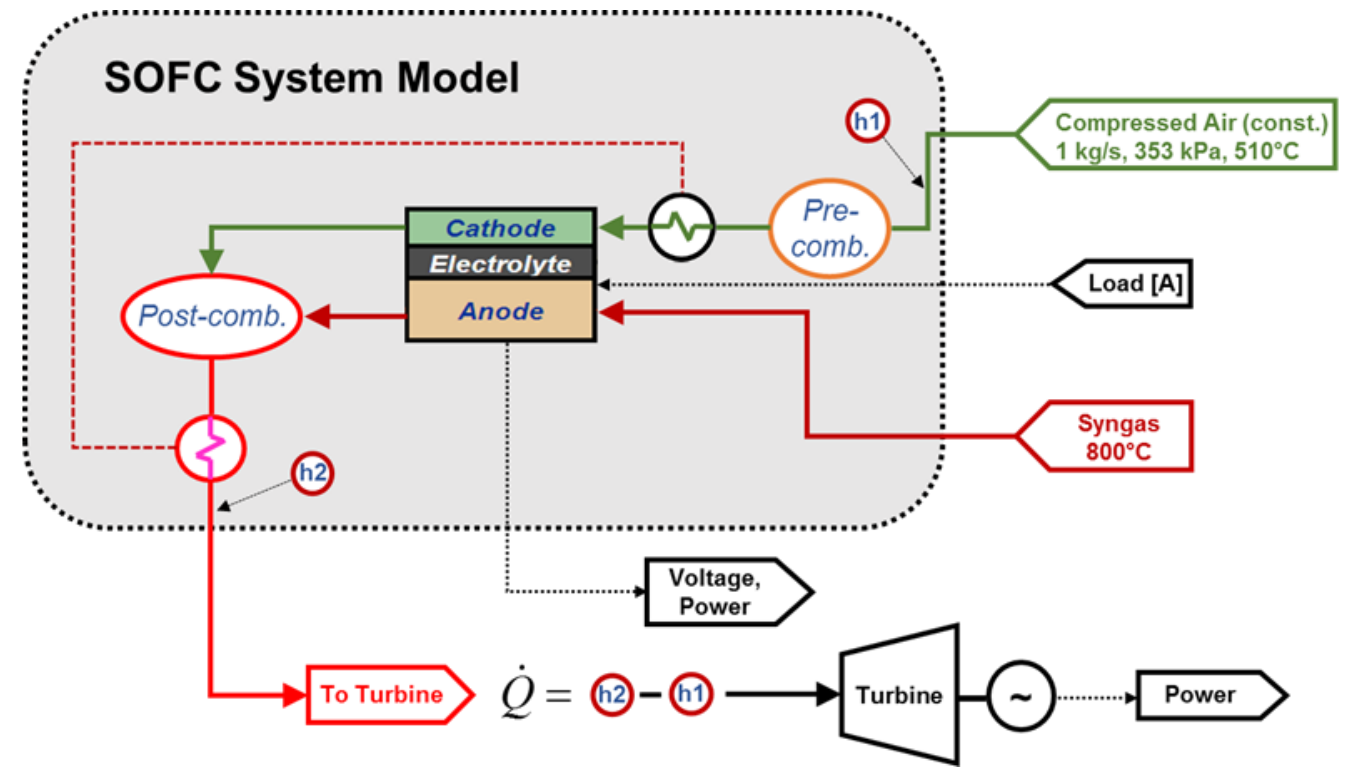

Fig. 2. SOFC system model in standalone configuration (a) and hybrid configuration (b)

Different PID controllers were applied to the system in both scenarios, as illustrated in the following section. All the controllers were developed in the same Simulink environment as the fuel cell model and tuned by trial-and-error.

\section{Control strategies}

Degradation causes a continuous decrease in the cell voltage, and consequently in the cell power output. In the standalone fuel cell, the only way to keep power constant as the voltage degraded was to increase the current, which increased degradation rate with time. A second controller incremented the fuel flow in order to maintain fuel utilization constant. As explained before, in a standalone fuel cell, fuel utilization needs to be kept high (80\% or more) to ensure high efficiency, and as constant as possible in order to prevent fuel starvation when the load increases. In a hybrid system, total power output could be maintained constant increasing the turbine load, i.e. the fuel flow to the system. Since the initial total efficiency was significantly higher than in a standalone fuel cell, there was no need to keep fuel utilization constant. The current could be held constant or decreased by a second controller in order to reduce degradation rate during time and keep constant voltage. In the latter case, a reduction in current induced higher Nernst potential to offset voltage degradation, and decreased cell overpotentials and degradation rate.

In addition, in each configuration, two other PID controllers were employed for fuel cell thermal management. The $\Delta \mathrm{T}$ in the cathode stream was kept constant by manipulating the airflow, while the average temperature of the cell was maintained constant by regulating the fuel flow of the pre-heating combustor. As such, thermal management of the cell during degradation was observed to be a critical issue [39]. In particular, localized temperature gradients and heat generation could present high peaks, which could be detrimental for the fuel cell solid structure. An adequate control of thermal parameters would require a separate study that is beyond the scope of this work. 
However, a simultaneous regulation of cathode airflow and inlet temperature was proven in the literature to be an effective strategy [24].

An additional option was finally considered in this work, relaxing the constant power assumption. If the system power is not required to be constant, we could keep constant cell voltage and reduce degradation even in the standalone case. The control of fuel utilization ensured high efficiency throughout the fuel cell life. This scenario was compared with a hybrid system where the voltage was kept constant and the total system power decreased with time. Fuel utilization was controlled in the standalone configuration (as in case 1) and let decrease in the hybrid system. A summary of the different considered scenarios is shown in Table 1.

Table 1. Summary of the different control strategies (in bold the driving assumptions)

\begin{tabular}{|c|c|c|c|c|c|}
\hline & Cell voltage & Cell power & Turbine power & $F U$ & Total Power \\
\hline $\begin{array}{c}\text { Case 1 } \\
\text { Standalone FC }\end{array}$ & $\downarrow$ & Constant & N/A & Constant & Constant \\
\hline $\begin{array}{c}\text { Case 2 } \\
\text { Hybrid system }\end{array}$ & $\downarrow$ & $\downarrow$ & $\uparrow$ & $\downarrow$ & Constant \\
\hline $\begin{array}{c}\text { Case 3 } \\
\text { Hybrid system }\end{array}$ & Constant & $\downarrow$ & $\uparrow$ & $\downarrow$ & Constant \\
\hline $\begin{array}{c}\text { Case 4 } \\
\text { Standalone FC }\end{array}$ & Constant & $\downarrow$ & N/A & Constant & $\downarrow$ \\
\hline $\begin{array}{c}\text { Case 5 } \\
\text { Hybrid system }\end{array}$ & Constant & $\downarrow$ & Constant & $\downarrow$ & $\downarrow$ \\
\hline
\end{tabular}

The selected criteria to determine the end of life are illustrated in Table 2 and discussed in the next sections.

Table 2. End-of-life conditions for the different scenarios

\begin{tabular}{|c|c|}
\hline $\begin{array}{c}\text { Case 1 } \\
\text { Standalone FC }\end{array}$ & Voltage $=0$ \\
\hline $\begin{array}{c}\text { Case } 2 \\
\text { Hybrid system }\end{array}$ & Voltage $=0$ \\
\hline $\begin{array}{c}\text { Case 3 } \\
\text { Hybrid system }\end{array}$ & $\begin{array}{c}\text { Stack power }=30 \% \\
\text { (Total system power is constant) }\end{array}$ \\
\hline $\begin{array}{c}\text { Case 4 } \\
\text { Standalone FC }\end{array}$ & Stack power $=50 \%$ \\
\hline $\begin{array}{c}\text { Case 5 } \\
\text { Hybrid system }\end{array}$ & Total system power $=50 \%$ \\
\hline
\end{tabular}

The initial conditions for both configurations are presented in Table 3. In both cases the cell started with the same average current density, fuel utilization and average temperature, in order to start with the same degradation conditions. Fuel composition was chosen according to the degradation experiments used to develop the model and represented a typical coal-derived syngas. 
Table 3. Initial conditions

\begin{tabular}{|c|c|c|c|}
\hline & Standalone FC & Hybrid System \\
\hline Airflow [kg/s] & \multicolumn{2}{|c|}{1.00} \\
\hline Stack pressure ratio & \multicolumn{2}{|c|}{200} \\
\hline Current load [A] & \multicolumn{2}{|c|}{830} \\
\hline Average cell temperature [ $\left.{ }^{\circ} \mathbf{C}\right]$ & \multicolumn{2}{|c|}{0.09} \\
\hline Fuel flow [kg/s] & \multicolumn{2}{|c|}{80} \\
\hline Fuel utilization [\%] & 325 & 330 \\
\hline Fuel composition & $29.1 \% \mathrm{H}_{2}, 28.6 \% \mathrm{CO}, 27.1 \% \mathrm{H}_{2} \mathrm{O}, 12.0 \% \mathrm{CO}_{2}, 3.2 \% \mathrm{~N}_{2}$ \\
\hline Stack power [kW] & \multicolumn{2}{|c|}{100} \\
\hline Turbine power [kW] & 0.79 & 0.82 \\
\hline Cell voltage [V] & & \\
\hline
\end{tabular}

Since the fuel cell in the hybrid configuration was pressurized, voltage was slightly higher than in the standalone case at the same initial current load.

The model was allowed to reach the steady-state condition before starting the cell degradation.

\section{Results and discussion}

\subsection{Cases 1, 2, and 3 - Constant power conditions}

A comparison of the fuel cell life in the first three different scenarios is presented in Figures 3 and 4 , which show fuel cell voltage and power respectively, during time. 


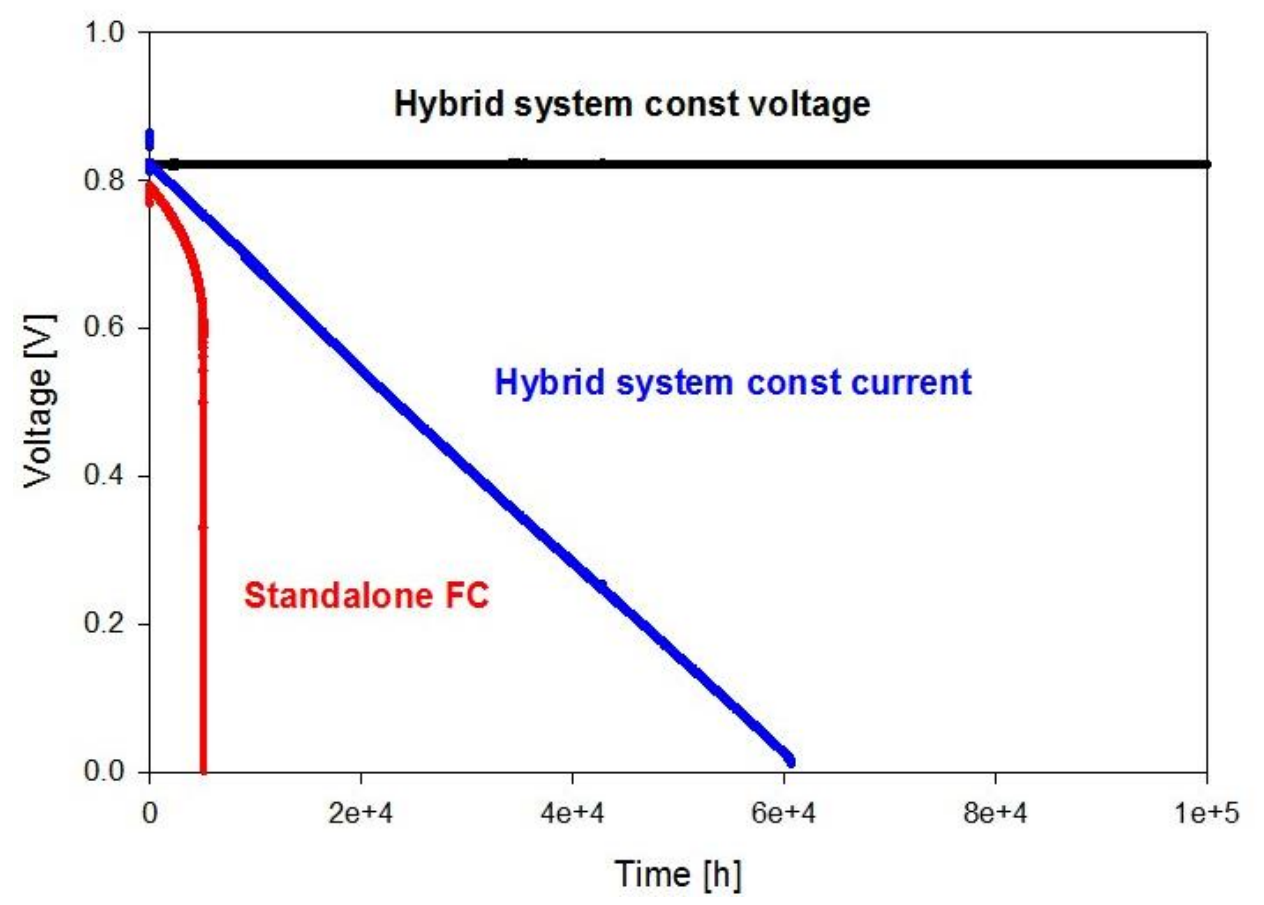

Fig. 3. Fuel cell voltage comparison in cases 1,2 , and 3 at constant power

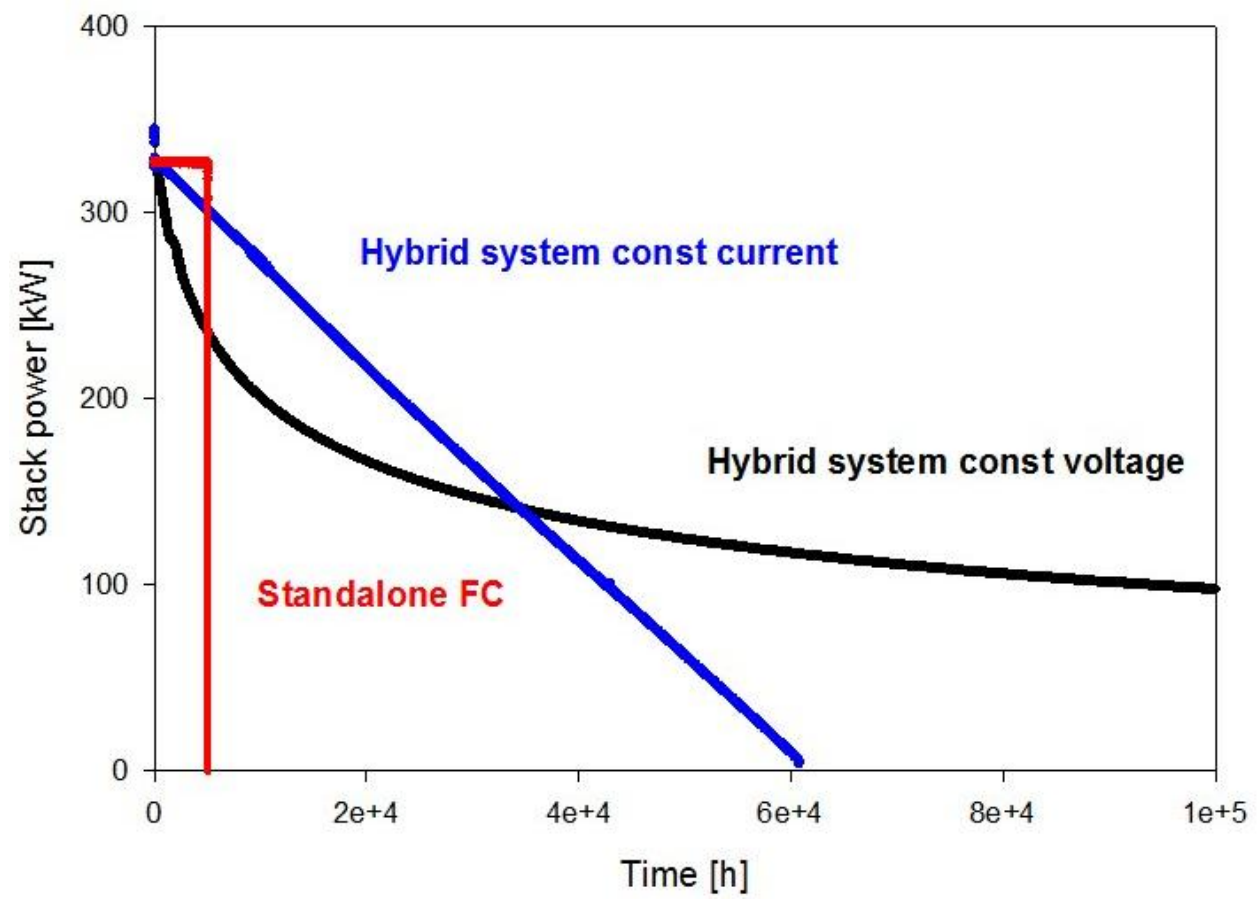

Fig. 4. Fuel cell stack power comparison in cases 1, 2, and 3

In the standalone fuel cell, degradation rate increased with time due to the increment in current load that was required to maintain constant power as the voltage degraded. This resulted in a quick drop in cell voltage, after only 6000 hours. The voltage curve presented a quasi-linear trend during the first $500 \mathrm{~h}$, followed by an inverse exponential decay and a sudden cell failure as the voltage reached about $80 \%$ of the nominal value. 
In the hybrid system, the life of the fuel cell was significantly longer in both cases. With constant current (case 2), the degradation rate actually decreased over time thanks to the reduction in fuel utilization as the fuel flow increased. Voltage degraded slowly, while the system power output was kept constant shifting more load to the turbine (as shown in Figure 5). Hence, cell voltage and fuel cell stack power gradually decreased to zero in around 60,000 h. In reality, we should consider that limitations exist in voltage decrement. This simplified model of degradation did not take into account nickel re-oxidation phenomena, which cause a fast performance degradation once the voltage gets below a threshold, typically around $80 \%$. As shown in Figure 3 , this would have occurred at around $20,000 \mathrm{~h}$. Considering this aspect, fuel cell life could be only be extended by a factor of three when compared with the standalone scenario. The second control strategy allowed by the hybrid configuration (case 3) could overcome this problem. When the voltage was maintained constant, reducing current load during time, fuel cell life could be extended even further. After $100,000 \mathrm{~h}$, fuel cell power decreased to $30 \%$ of its nominal value and the stack did not fail during this time.

Figure 5 illustrates the turbine power versus time in the hybrid system. As fuel cell power degraded, turbine load was increased in order to maintain the same system power output over time, considering a constant demand from the grid.

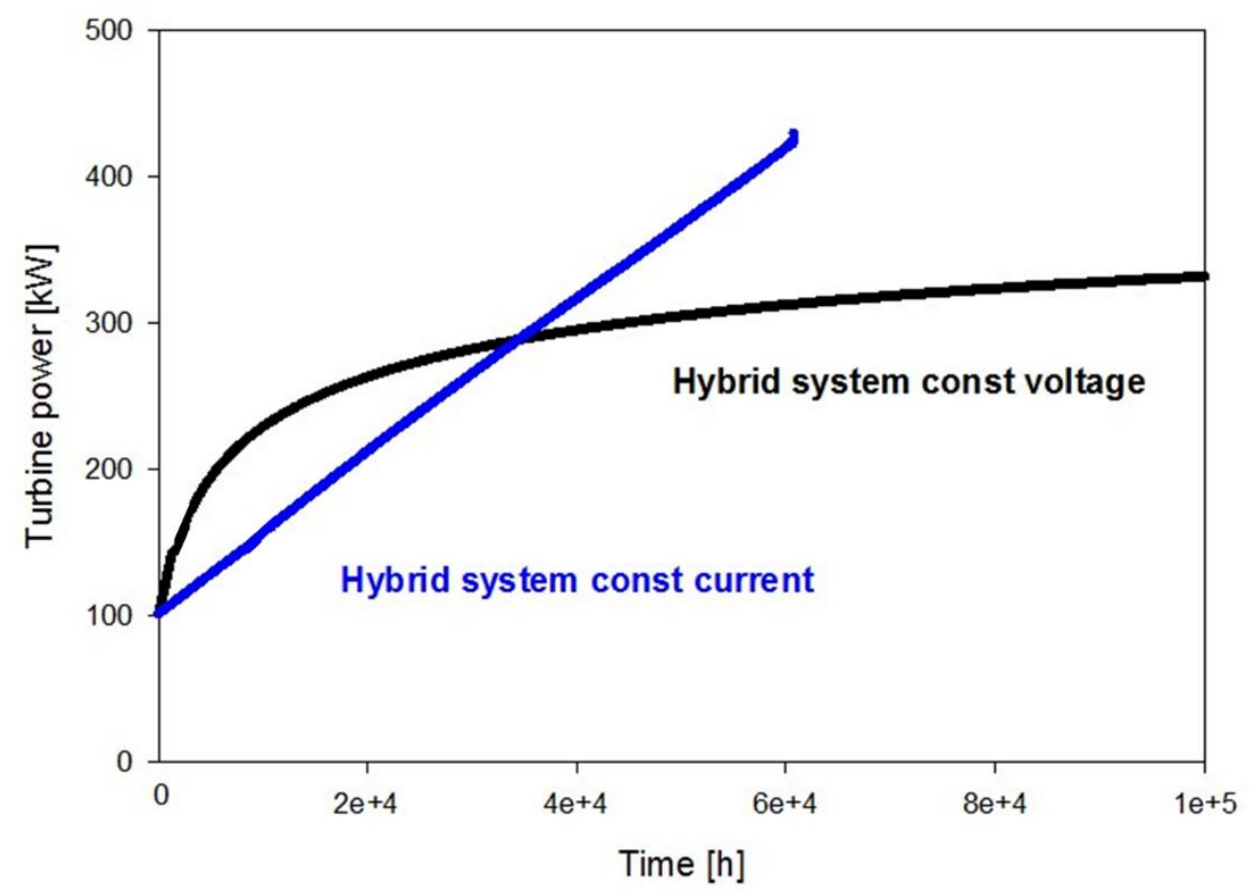

Fig. 5. Turbine power trends during time in the hybrid system of cases 2 and 3

In the hybrid system of cases 2 and 3, a controller increased the anode fuel flow over time, resulting in more available heat from the combustion of the unutilized fuel. The available heat from the fuel cell system drove the turbine, incrementing the generated power. In addition, a decrement in fuel utilization was beneficial for the fuel cell because it reduced the degradation rate and increased the Nernst potential, offsetting voltage degradation.

For both these control strategies, the turbine would need to be oversized and work in part-load conditions at the beginning of plant life. Based on the control strategy chosen, the initial size of the 
turbine would determine the life of the fuel cell. For instance, if a $350 \mathrm{~kW}$ turbine size was chosen, fuel cell life could be extended up to $45,000 \mathrm{~h}$ in this model in a constant current control mode. As such, once the turbine gets to nominal power, the total system power could only decrease during time as the cell keeps degrading. Operating in a constant voltage mode, the turbine load increased more gradually, reaching nominal load condition after more than $100,000 \mathrm{~h}$. Thus, the control strategy of case 3 was considered globally more advantageous than case 2 .

The benefit of an oversized turbine and its optimal size should be evaluated with a complete techno-economic analysis, which is the objective of a future work. Since the state-of-the-art fuel cell is the most expensive component of the plant, it is reasonable to assume that extending the life by an order of magnitude would be economically beneficial, even considering the higher cost of a bigger turbine that works in off-design conditions for most part of its operating life.

A comparison of the system efficiencies, calculated on syngas LHV, is presented in Figure 6. Coal gasification efficiency and auxiliaries were not taken into account. In the hybrid system, the total system efficiency was higher than in a standalone configuration during the entire lifetime, especially when cell voltage was kept constant. As a matter of fact, with the proposed control strategies, Nernst potential was increased during time, maintaining a higher fuel cell efficiency. The turbine efficiency was quite low at the beginning of life due to the part-load operating condition, and increased over time as more power was generated. Thus, fuel cell efficiency degradation was compensated by improved turbine performance. In particular, a constant voltage mode resulted in a fairly constant system efficiency during time, always above $60 \%$. In fact, after an initial drop, the increase in turbine performance offset fuel cell efficiency reduction, which was fairly slow after 20,000 hours as expected from the stack power trend.

Obviously, gas turbine off-design performance depends on the turbine size, hence a more accurate analysis of system efficiency requires an evaluation of the optimal size of the turbine. However, this is beyond the purpose of this paper and will be object of future work.

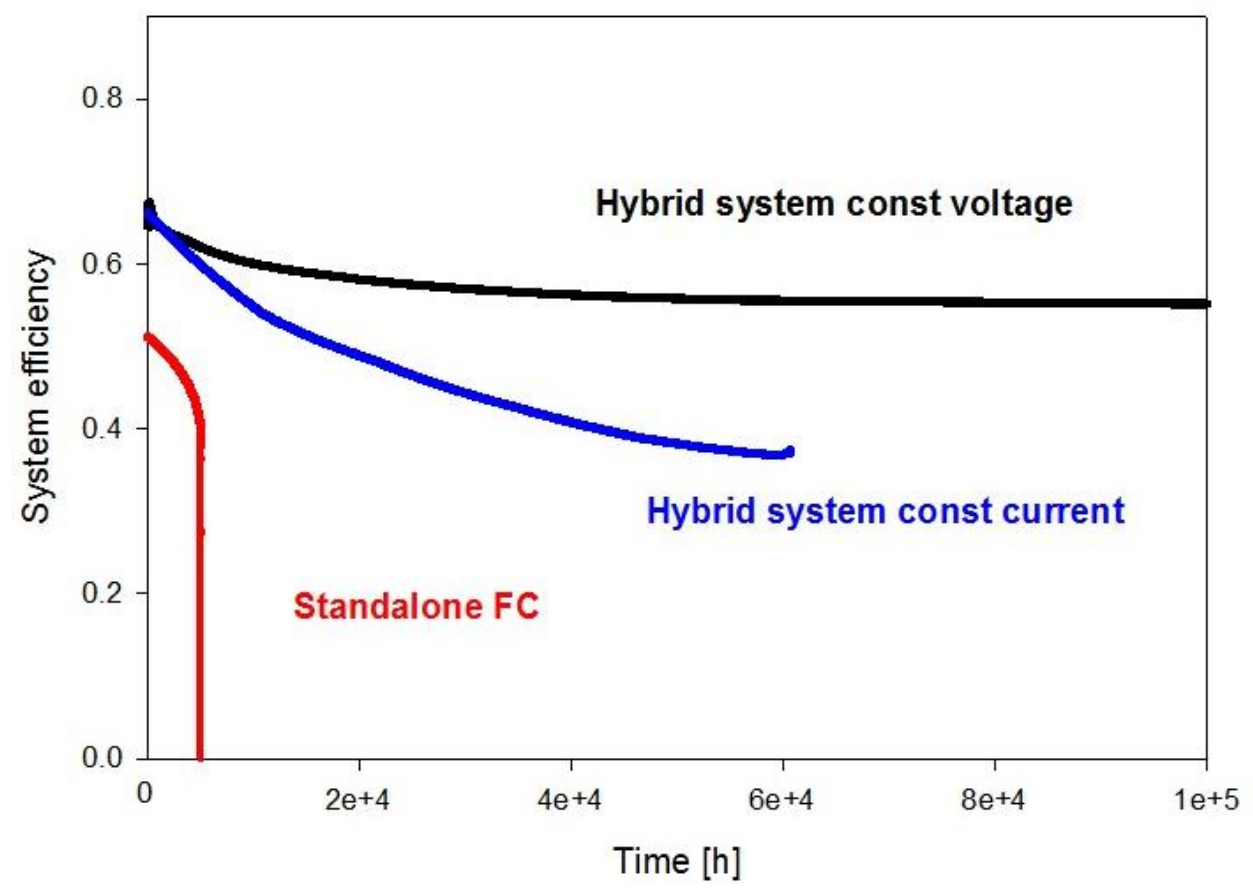

Fig. 6. Efficiency comparison in cases 1, 2, and 3 
The overall degradation rate during time, calculated according to Eq. 6, is shown in Figure 7. Since the initial conditions of the cell were the same in all the three cases (1-3), the degradation rate started at the same value, around $1 \% / \mathrm{kh}$. In the standalone fuel cell, the increasing current caused the degradation rate to increase exponentially with time, as mentioned before. In the hybrid system, degradation rate was observed to follow a slow linear decay when the current was kept constant, and to decrease significantly during time in the case of constant voltage.

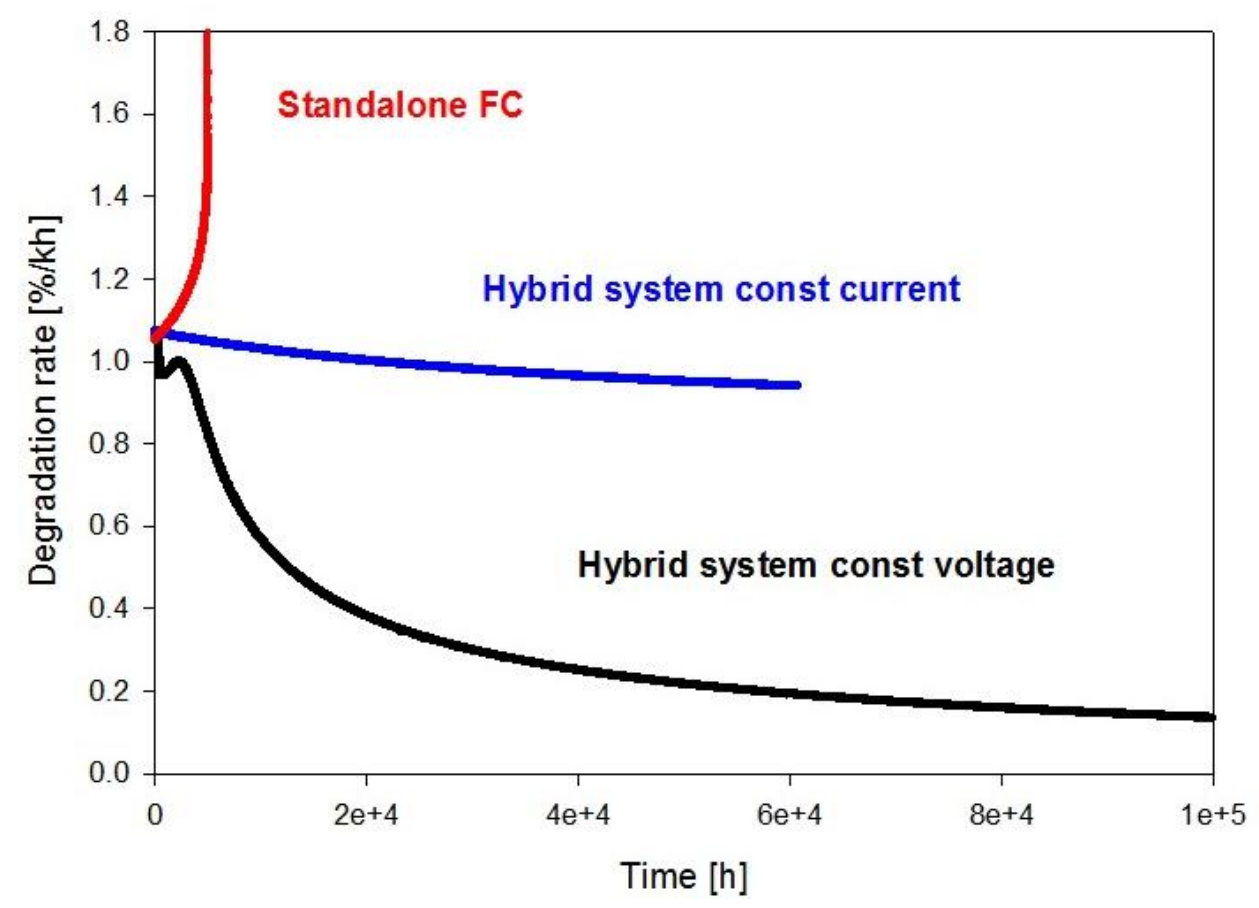

Fig. 7. Comparison of the degradation rate trends in cases 1, 2, and 3

\subsection{Cases 4 and 5 - Degrading power}

Two other options were considered for completeness, assuming that the system power was not required to be constant during time. Hence, in the standalone case, voltage could be kept constant letting the power degrade and extending the fuel cell life at the cost of producing less electrical power. In the hybrid system, we assumed the turbine to be sized optimally at the beginning of life of the plant matching the fuel cell size. Therefore, the initial turbine power was $160 \mathrm{~kW}$ and was constant over time while the cell power was degrading. The benefit of these two final strategies should be evaluated with an economic study to take into account the losses in sold electricity and the enhanced cell durability in case of the standalone stack, and the lower initial capital investment in case of the hybrid system due to a smaller turbine.

The results of these two final simulations are presented in Figures 8 and 9, which show total system power and system efficiency respectively. The end of operating life in these two cases was determined as the system power achieved $50 \%$ of the initial value. This is an arbitrary choice, and the evaluation of the optimal condition will also be part of the future economic analysis. 


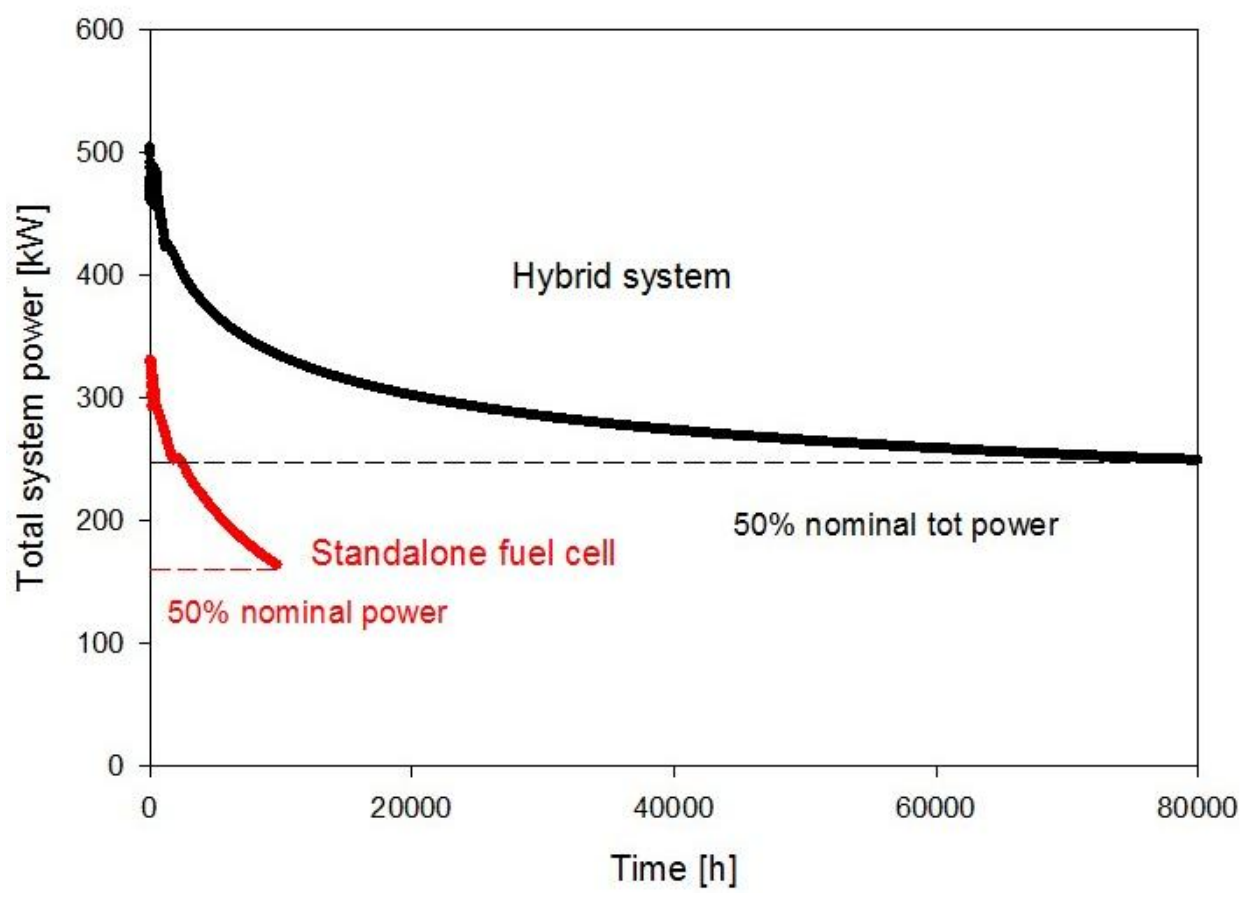

Fig. 8. Fuel cell power comparison for cases 4 and 5

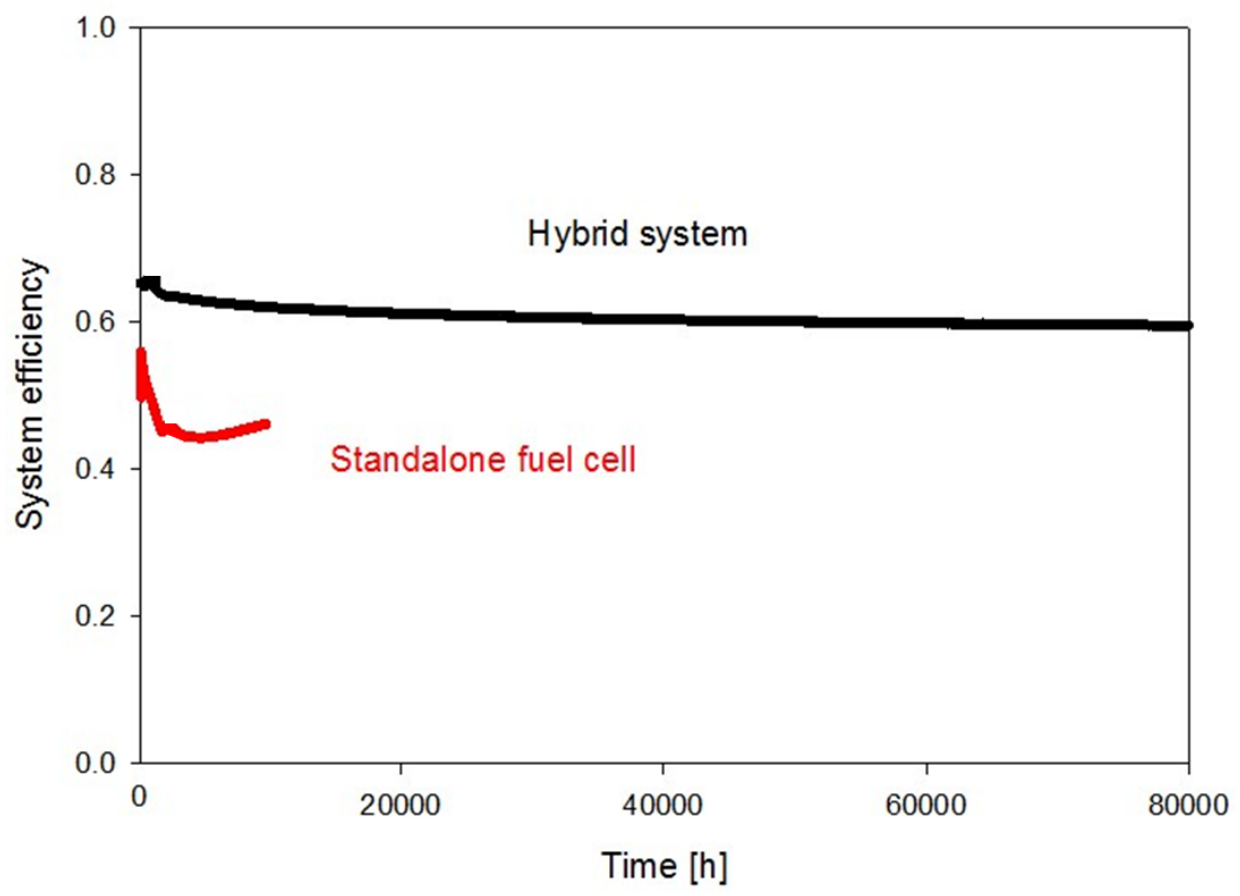

Fig. 9. Efficiency comparison between cases 4 and 5

As Figure 8 shows, in the standalone fuel cell when voltage was kept constant, power decreased to $50 \%$ in $10,000 \mathrm{~h}$ (lifetime around $70 \%$ more than case 1). Since both voltage and fuel utilization were constant, efficiency of the stack was not penalized as much as in case 1, remaining always above $45 \%$ during the lifetime (Figure 9). Comparing the trends of stack power and fuel flow, depicted in Figure 10, the fuel flow rate showed a steeper decrement after the first $2000 \mathrm{~h}$, resulting in a slight efficiency increase over time despite degradation. 
In the hybrid system of case 5, turbine power was maintained constant at the design condition $(160 \mathrm{~kW})$ decreasing the fuel flow as fuel cell power degraded. Turbine efficiency was assumed $30 \%$. The higher fuel utilization induced a slightly worse degradation compared with case 3 , and the end of life was achieved after $80,000 \mathrm{~h}$, when the stack power was $27 \%$ of initial value. In contrast, the lower amount of fuel and the higher turbine efficiency allowed a higher, more uniform total system efficiency.

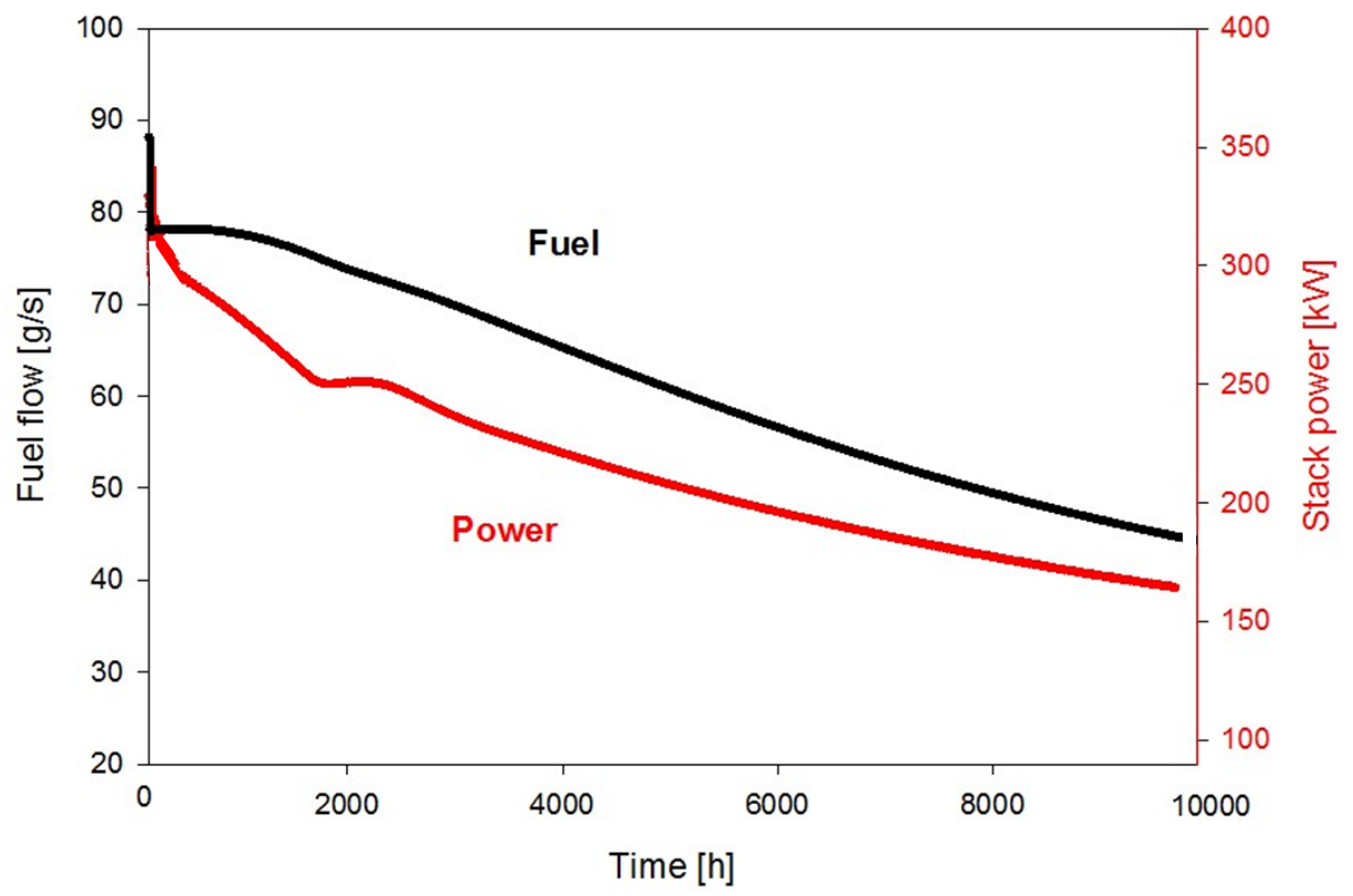

Fig. 10. Stack power and fuel flow trends in the standalone FC of case 4

A preliminary economic analysis was performed with the assumptions of Table 4 to evaluate the most beneficial strategy. The goal was only to compare the different cases starting from the same assumptions, but a more extensive analysis will be part of a future study.

Table 4. Economic assumptions

\begin{tabular}{|c|c|}
\hline Component & Cost \\
\hline SOFC stack & $300 \$ / \mathrm{kW} \mathrm{[42]}$ \\
\hline Gas turbine & $700 \$ / \mathrm{kW} \mathrm{[43]}$ \\
\hline Exhaust gas recuperator & $50 \%$ turbine cost $[43]$ \\
\hline SOFC blower & $10 \%$ stack cost $[44]$ \\
\hline SOFC inverter & $10 \%$ stack cost $[44]$ \\
\hline Annual maintenance $\left(C_{\text {main }}\right)$ & $3 \%$ capital investment \\
\hline Electricity price $\left(P_{e l}\right)$ & $0.15 \$ / \mathrm{kWh}$ \\
\hline Fuel price $\left(P_{f}\right)$ & $0.1 \$ / \mathrm{kg}$ \\
\hline Internal rate to actualize cash flow $(r)$ & 0.01 \\
\hline
\end{tabular}


Economic performance were evaluated in terms of payback period (PBP) and Net Present Value (NPV) at 20 years, calculated according to Equations 11-13.

$$
\begin{aligned}
& T C I=\sum_{j=1}^{P B P} C F_{j} \\
& C F_{j}=E_{e l} P_{e l}-C_{f} P_{f}-C_{\text {main }} \\
& N P V=\sum_{j=1}^{20} \frac{C F_{j}}{(1+r)^{j}}-T C I
\end{aligned}
$$

The results, presented in Table 5, showed how the standalone fuel cell system (cases 1 and 4) had a PBP longer than 20 years with both the operating strategies. Despite the longer lifetime, the constant voltage strategy resulted in a long PBP and a negative NPV because of the reduction in sold electricity over time. In contrast, the hybrid system showed a short PBP in all cases with significant economic benefits. However, these results are strongly influenced by stack price and turbine size, hence a more detailed analysis needs to be completed in the future for an accurate economic assessment.

Table 5. Economic results

\begin{tabular}{|c|c|c|}
\hline Case & PBP [years] & NPV [\% TCI] \\
\hline $\begin{array}{c}\text { Case 1 } \\
\text { Standalone FC }\end{array}$ & 61.1 & -383 \\
\hline $\begin{array}{c}\text { Case 2 } \\
\text { Hybrid system }\end{array}$ & 5.2 & 221 \\
\hline $\begin{array}{c}\text { Case 3 } \\
\text { Hybrid system } \\
\text { Case 4 } \\
\text { Standalone FC }\end{array}$ & 2.7 & 419 \\
\hline $\begin{array}{c}\text { Case 5 } \\
\text { Hybrid system }\end{array}$ & 49.0 & -139 \\
\hline
\end{tabular}

\section{Conclusions and future work}

The impact on fuel cell life of five different control strategies was evaluated for a standalone, atmospheric SOFC stack and a pressurized SOFC gas turbine hybrid system. Regulation of fuel cell current, temperature, and fuel utilization was considered in order to mitigate the effects of cell degradation on system performance and lifetime. Three possibilities were considered for the fuel cell operations: constant current, constant voltage, and constant stack power modes. In addition, two options were assumed for the turbine: off-design operations and constant power operations.

The hybridization of SOFC and gas turbine presented more flexibility in terms of possible control strategies, extending the lifetime by an order of magnitude with respect to the standalone stack. This was demonstrated either when constant system power was required or when the power was allowed to degrade. From these results, maintaining constant cell voltage in a hybrid system at constant total system power was the most advantageous operating strategy. Depending on the turbine size, the fuel cell lifetime could go beyond $100,000 \mathrm{~h}$ of operation even with a relatively 
high initial degradation rate of $1 \% / \mathrm{kh}$. The system performance was observed to be higher than in the standalone fuel cell stack throughout the whole operating life.

Allowing the power to degrade could be a viable option for extending the lifetime of the standalone fuel cell by $70 \%$ (comparing case 4 to case 1), at the cost of selling less electrical power. For the hybrid system, this option would have the advantage to require a smaller turbine and keep higher system efficiency over time (comparing case 5 to cases 2 and 3). A summary of the lifetime in the five different cases is presented in Table 6.

Table 6. Lifetime summary

\begin{tabular}{|c|c|}
\hline $\begin{array}{c}\text { Case 1 } \\
\text { Standalone FC }\end{array}$ & $5,900 \mathrm{~h}$ \\
\hline $\begin{array}{c}\text { Case 2 } \\
\text { Hybrid system }\end{array}$ & $\begin{array}{c}60,800 \mathrm{~h} \text { (at zero voltage) } \\
\text { Case 3 } \\
\text { Hybrid system }\end{array}$ \\
\hline $\begin{array}{c}\text { Case 4 } \\
\text { Standalone FC } \\
\text { Case 5 } \\
\text { Hybrid system }\end{array}$ & $>100,000 \mathrm{~h}$ \\
\hline
\end{tabular}

A preliminary cursory economic analysis showed the significant benefits in terms of PBP and NPV of hybridizing fuel cell and gas turbine. However, a more detailed analysis is needed as future step to better assess the economic benefits of these results and determine the optimal turbine size. A detailed analysis of fuel cell localized parameters is also necessary, for a deeper understanding of operating condition effects during degradation. These results will be used in the future in the European project "BioHypp" to operate a real fuel cell gas turbine hybrid system.

\section{Acknowledgments}

The work was funded by the U.S. Department of Energy Enabling Technology and Partnership Program of the National Energy Technology Laboratory (NETL), and was supported in part by the NETL Research Participation Program, administrated by Oak Ridge Institute for Science and Education.

\section{References}

[1] V. Liso, A.C. Olesen, M.P. Nielsen, S.K. Kær, "Performance comparison between partial oxidation and methane steam reforming processes for solid oxide fuel cell (SOFC) micro combined heat and power (CHP) system", Energy 36 (2011) 4216 - 4226, doi:10.1016/j.energy.2011.04.022.

[2] D. Tucker, E. Liese, R. Gemmen, "Determination of the operating envelope for a direct fired fuel cell turbine hybrid using hardware based simulation”, ICEPAG 2009-1021. 
[3] F. Mueller, R. Gaynord, A.E. Auld, J. Brouwer, F. Jabbari, S. Samuelsen, "Synergistic integration of a gas turbine and solid oxide fuel cell for improved transient capability", J. Power Sources 176 (2008) 229-239, doi: 10.1016/j.jpowsour.2007.10.081.

[4] B. Tarroja, F. Mueller, J. Maclay, J. Brouwer, "Parametric thermodynamic analysis of a solid oxide fuel cell gas turbine system design space", Journal of Engineering for Gas Turbines and Power 132(7) (2010) 072301, doi:10.1115/1.4000263.

[5] A.F. Massardo, F. Lubelli, "Internal reforming solid oxide fuel cell - gas turbine combined cycles (IRSOFC-GT): Part A - Cell model and cycle", Journal of Engineering for Gas Turbines and Power 122(1) (2000) 27 - 35, doi: 10.1115/1.483187.

[6] V. Eveloy, "Numerical analysis of an internal methane reforming solid oxide fuel cell with fuel recycling", Applied Energy 93 (2012) 107-115, doi:10.1016/j.apenergy.2010.10.045.

[7] K. Park, S. Yu, J. Bae, H. Kim, Y. Ko, "Fast Performance Degradation of SOFC Caused by Cathode Delamination in Long-term Testing”, International Journal of Hydrogen Energy, 35 (2010) 8670-8677, doi:10.1016/j.ijhydene.2010.05.005.

[8] A. Nakajo, Z. Wuillemin, J. Van herle, D. Favrat, "Simulation of thermal stresses in anodesupported solid oxide fuel cell stacks. Part I: Probability of failure of the cells", Journal of Power Sources 193 (2009) 203-215, doi:10.1016/j.jpowsour.2008.12.050.

[9] J. Bao, G.N. Krishnan, P. Jayaweera, J. Perez-Mariano, A. Sanjurjo, "Effect of Various Coal Contaminants on the Performance of Solid Oxide Fuel Cells: Part I. Accelerated Testing", Journal of Power Sources 193 (2009) 607- 616, doi:10.1016/j.jpowsour.2009.04.034.

[10] J.P. Trembly, A.I. Marquez, T.R. Ohrn, D.J. Bayless, "Effects of coal syngas and H2S on the performance of solid oxide fuel cells: Single-cell tests", Journal of Power Sources 158 (2006) 263-273, doi:10.1016/j.jpowsour.2005.09.055.

[11] T. Ma, M. Yan, M. Zeng, J. Yuan, Q. Chen, B. Sundén, Q. Wang, "Parameter study of transient carbon deposition effect on the performance of a planar solid oxide fuel cell", Applied Energy 152 (2015) 217-228, doi.org/10.1016/j.apenergy.2014.11.061.

[12] A. Hagen, R. Barfod, P.V. Hendriksen, "Degradation of Anode Supported SOFCs as a Function of Temperature and Current Load", J. of Electrochem. Soc., 153 (2006) A1165 A1171, doi: 10.1149/1.2193400.

[13] A. Nakajo, F. Mueller, J. Brouwer, J. van Herle, D. Favrat, "Progressive activation of degradation processes in solid oxide fuel cells stacks: Part I: Lifetime extension by optimisation of the operating conditions", Journal of Power Sources 216 (2012) 449-463, doi:10.1016/j.jpowsour.2012.05.078.

[14] R.S. Gemmen, M.C. Williams, K. Gerdes, "Degradation measurement and analysis for cells and stacks", Journal of Power Sources 184 (2008) 251-259, doi: 10.1016/j.jpowsour.2008.06.047.

[15] D. Tucker, N.F. Harun, M. Abreu, "SOFC Lifetime Assessment in Gas Turbine Hybrid Systems", Journal of Fuel Cell Science and Technology 11(5) (2014) 051008, doi: 10.1115/1.4028953.

[16] L. Barelli, G. Bidini, A. Ottaviano, "Part load operation of a SOFC/GT hybrid system: Dynamic analysis", Applied Energy $110 \quad$ (2013) 173 - 189, doi: 10.1016/j.apenergy.2013.04.011.

[17] D.P. Bakalis, A.G. Stamatis, "Incorporating available micro gas turbines and fuel cell: Matching considerations and performance evaluation", Applied Energy 103 (2013) 607617, doi: 10.1016/j.apenergy.2012.10.026. 
[18] A. Al-Masri, M. Peksen, L. Blum, D. Stolten, "A 3D CFD model for predicting the temperature distribution in a full scale APU SOFC short stack under transient operating conditions", Applied Energy 135 (2014) 539-547, doi:10.1016/j.apenergy.2014.08.052.

[19] M. Fardadi, F. Mueller, F. Jabbari, "Feedback control of solid oxide fuel cell spatial temperature variation", Journal of Power Sources 195 (2010) 4222-4233, doi:10.1016/j.jpowsour.2009.12.111.

[20] F. Mueller, F. Jabbari, R. Gaynor, J. Brouwer, "Novel solid oxide fuel cell system controller for rapid load following”, Journal of Power Sources 172 (2007) 308-323, doi:10.1016/j.jpowsour.2007.05.092.

[21] Y. Komatsu, G. Brus, S. Kimijima, J.S. Szmyd, "The effect of overpotentials on the transient response of the 300 W SOFC cell stack voltage", Applied Energy 115 (2014) 352 359, doi:10.1016/j.apenergy.2013.11.017.

[22] M.L. Ferrari, “Advanced control approach for hybrid systems based on solid oxide fuel Cells”, Applied Energy 145 (2015) 364-373, doi: 10.1016/j.apenergy.2015.02.059.

[23] D. Vrecko, G. Dolanc, B. Dolenc, D. Vranĉić, B. Pregelj, D. Marra, M. Sorrentino, C. Pianese, A. Pohjoranta, and Đ. Juričić, "Feedforward-Feedback Control of a SOFC Power System: A Simulation Study”, ECS Transaction 2015, DOI: 10.1149/06801.3151ecst.

[24] Y. Inui, N. Ito, T. Nakajima, A. Urata, "Analytical Investigation on Cell Temperature Control Method of Planar Solid Oxide Fuel Cell", Energy Conversion and Management 47 (2006) 2319-2328, doi:10.1016/j.enconman.2005.11.007.

[25] R. Gaynor, F. Mueller, F. Jabbari, J. Brouwer, "On control concepts to prevent fuel starvation in solid oxide fuel cells", Journal of Power Sources 180(1) (2008) 330-342, doi: 10.1016/j.jpowsour.2008.01.078.

[26] P. Aguiar, C.S. Adjiman, N.P. Brandon, Anode-supported intermediate temperature direct internal reforming solid oxide fuel cell. II: Model-based dynamic performance and control, Journal of Power Sources 147 (2005) 136-147, doi:10.1016/j.jpowsour.2005.01.017.

[27] B.J. Spivey, T.F. Edgar, "Dynamic modeling, simulation, and MIMO predictive control of a tubular solid oxide fuel cell", Journal of Process Control 22 (2012) 1502 - 1520, doi:10.1016/j.jprocont.2012.01.015.

[28] S.A. Hajimolana, S.M. Tonekabonimoghadam, M.A. Hussain, M.H. Chakrabarti, N.S. Jayakumar, M.A. Hashim, "Thermal stress management of a solid oxide fuel cell using neural network predictive control”, Energy $62 \quad$ (2013) $320 \quad-\quad 329$, doi:10.1016/j.energy.2013.08.031.

[29] A. Pohjoranta, M. Halinen, J. Pennanen, J. Kiviaho, "Model predictive control of the solid oxide fuel cell stack temperature with models based on experimental data", Journal of Power Sources 277 (2015) 239-250, http://dx.doi.org/10.1016/j.jpowsour.2014.11.126.

[30] L. Larosa, A. Traverso, M.L. Ferrari, V. Zaccaria, "Pressurized SOFC Hybrid System: Control System Study and Experimental Verification", Journal of Engineering for Gas Turbine and Power 137 (2015) 031602-1, DOI: 10.1115/1.4028447.

[31] B. Huang, Y. Qi, A.K.M. Monjur Murshed, "Dynamic Modeling and Predictive Control in Solid Oxide Fuel Cells: First Principle and Data-Based Approaches, J. Wiley and Sons Ltd. 2013. 
[32] B. Pregelj, D. Vrečko, V. Jovan, "Improving the Operation of a Fuel Cell Power Unit with Supervision Control - A Simulation Study”, Journal of Power Sources 196(22) (2011) 94199428, doi:10.1016/j.jpowsour.2011.06.077.

[33] P. Adhikari, M. Abdelrahman, "Multilevel supervisory control of a standalone hybrid fuel cell power system", DOI: 10.1109/NAPS.2010.5618979.

[34] L. Xu, J. Li, J. Hua, X. Li, M. Ouyang, "Adaptive supervisory control strategy of a fuel cell/battery-powered city bus", Journal of Power Sources 194 (2009) 360-368, doi:10.1016/j.jpowsour.2009.04.074.

[35] R. Roshandel, T. Parhizkar, "Degradation based optimization framework for long term applications of energy systems, case study: Solid oxide fuel cell stack”, Energy 107 (2016) 172-181, doi:10.1016/j.energy.2016.04.007.

[36] D. Hughes, W.J. Wepfer, K. Davies, C. Haynes, D. Tucker, "A Real-time Spatial SOFC Model for Hardware-Based Simulation of Hybrid Systems", Proceeding of ASME 2011 9th International Conference on Fuel Cell Science, Engineering and Technology, pp. 409-428, doi:10.1115/FuelCell2011-54591.

[37] V. Verda, M.R. von Spakovsky, "Development of a Detailed Planar Solid Oxide Fuel Cell Computational Fluid Dynamics Model for Analyzing Cell Performance Degradation”, Journal of Fuel Cell Science and Technology 6(1) (2008) 011005, doi: 10.1115/1.2971046.

[38] V. Zaccaria, D. Tucker, A. Traverso, "A distributed real-time model of degradation in a solid oxide fuel cell, Part I: Model characterization”, Journal of Power Sources 311 (2016) 175 - 181, doi:10.1016/j.jpowsour.2016.02.040.

[39] V. Zaccaria, D. Tucker, A. Traverso, "A distributed real-time model of degradation in a solid oxide fuel cell, Part II: Analysis of fuel cell performance and potential failures", Journal of Power Sources (2016), doi:10.1016/j.jpowsour.2016.01.027.

[40] J. Nease, T.A. Adams II, "Comparative life cycle analyses of bulk-scale coal-fueled solid oxide fuel cell power plants", Applied Energy 150 (2015) 161-175, doi: 10.1016/j.apenergy.2015.03.105.

[41] V. Zaccaria, Z. Branum, D. Tucker, "Fuel Cell Temperature Control with a Pre-Combustor in SOFC Gas Turbine Hybrids during Load Changes", Proceedings of the ASME 2016 14th International Conference on Fuel Cell Science, Engineering and Technology, Charlotte, NC.

[42] M. Weimar, L. Chick, D. Gotthold, G. Whyatt, "Cost study for manufacturing of solid oxide fuel cell power systems”, U.S. Department of Energy 2013 Sep: 24-50, Report number PNNL-22732.

[43] M.A. Rosa do Nascimento, L. de Oliveira Rodrigues, E. Cruz dos Santos, E.E. Batista Gomes, F.L. Goulart Dias, E.I. Gutiérrez Velásques, R.A.M. Carrillo, "Micro Gas Turbine Engine: A Review", http://dx.doi.org/10.5772/54444.

[44] A. Arsalis, "Thermoeconomic modeling and parametric study of hybrid SOFC-gas turbinesteam turbine power plants ranging from 1.5 to $10 \mathrm{MWe}$, Journal of Power Sources 181 (2008) 313-326, doi:10.1016/j.jpowsour.2007.11.104. 